\title{
Minor effect of physical size sorting on iron solubility of transported mineral dust
}

\author{
Z. B. Shi ${ }^{1,{ }^{*} \text {, M. T. Woodhouse }}{ }^{1}$, K. S. Carslaw ${ }^{1}$, M. D. Krom ${ }^{1}$, G. W. Mann ${ }^{1,2}$, A. R. Baker ${ }^{3}$, I. Savov ${ }^{1}$, G. R. Fones ${ }^{4}$, \\ B. Brooks ${ }^{1}$, N. Drake ${ }^{5}$, T. D. Jickells ${ }^{3}$, and L. G. Benning ${ }^{1}$ \\ ${ }^{1}$ School of Earth and Environment, University of Leeds, Leeds, UK \\ ${ }^{2}$ National Centre for Atmospheric Science (NCAS), University of Leeds, UK \\ ${ }^{3}$ School of Environmental Sciences, University of East Anglia, Norwich, UK \\ ${ }^{4}$ School of Earth and Environmental Sciences, University of Portsmouth, Portsmouth, UK \\ ${ }^{5}$ Department of Geography, King's College London, London, UK \\ "now at: School of Geography, Earth and Environmental Sciences, University of Birmingham, Birmingham, UK
}

Received: 12 April 2011 - Published in Atmos. Chem. Phys. Discuss.: 10 May 2011

Revised: 15 July 2011 - Accepted: 15 August 2011 - Published: 19 August 2011

\begin{abstract}
Observations show that the fractional solubility of $\mathrm{Fe}$ (FS-Fe, percentage of dissolved to total $\mathrm{Fe}$ ) in dust aerosol increases considerably from $0.1 \%$ in regions of high dust mass concentration to $80 \%$ in remote regions where concentrations are low. Here, we combined laboratory geochemical measurements with global aerosol model simulations to test the hypothesis that the increase in FS-Fe is due to physical size sorting during transport. We determined the FS-Fe and fractional solubility of $\mathrm{Al}$ (FS-Al) in size-fractionated dust generated from two representative soil samples collected from known Saharan dust source regions using a customized dust re-suspension and collection system. The results show that the FS-Fe is size-dependent and ranges from $0.1-0.3 \%$ in the coarse size fractions $(>1 \mu \mathrm{m})$ to $\sim 0.2-0.8 \%$ in the fine size fractions $(<1 \mu \mathrm{m})$. The FS$\mathrm{Al}$ shows a similar size distribution to that of the FS-Fe. The size-resolved FS-Fe data were then combined with simulated dust mass concentration and size distribution data from a global aerosol model, GLOMAP, to calculate the FS-Fe of dust aerosol over the tropical and subtropical North Atlantic Ocean. We find that the calculated FS-Fe in the dust aerosol increases systematically from $\sim 0.1 \%$ at high dust mass concentrations (e.g., $>100 \mu \mathrm{g} \mathrm{m}^{-3}$ ) to $\sim 0.2 \%$ at low concentrations $\left(<100 \mu \mathrm{g} \mathrm{m}^{-3}\right)$ due to physical size sorting (i.e., particle gravitational settling). These values are one to two orders of magnitude smaller than those observed on cruises across the tropical and sub-tropical North Atlantic Ocean under an important pathway of Saharan dust plumes for simi-
\end{abstract}

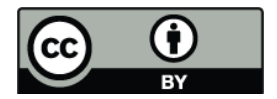

Correspondence to: Z. B. Shi

(z.shi@bham.ac.uk) lar dust mass concentrations. Even when the FS-Fe of submicrometer size fractions $(0.18-0.32 \mu \mathrm{m}, 0.32-0.56 \mu \mathrm{m}$, and $0.56-1.0 \mu \mathrm{m})$ in the model is increased by a factor of 10 over the measured values, the calculated FS-Fe of the dust is still more than an order of magnitude lower than that measured in the field. Therefore, the physical sorting of dust particles alone is unlikely to be an important factor in the observed inverse relationship between the FS-Fe and FS-Al and the atmospheric mineral dust mass concentrations. The results suggest that processes such as chemical reactions and/or mixing with combustion particles are the main mechanisms to cause the increased FS-Fe in long-range transported dust aerosols.

\section{Introduction}

One of the most significant recent advances in oceanography was the demonstration of the importance of Fe supply in regulating key biogeochemical interactions and feedbacks between the ocean and atmosphere (Martin et al., 1990; Turner et al., 1996; Boyd et al., 2007, 2010) together with the recognition that atmospheric mineral aerosol (dust) is a primary external source of $\mathrm{Fe}$ found in surface waters (Martin, 1990; Duce et al., 1991; Jickells and Spokes, 2001; Jickells et al., 2005; Rikenberg et al., 2008; Guieu et al., 2010; Theodosi et al., 2010). The supply of bioavailable Fe to surface waters has been shown to be important in the regulation of primary productivity and nitrogen fixation rates, resulting in altered carbon uptake and biogenic air-sea gas fluxes, which have feedback effects on climate and dust production (Jickells et al., 2005; Mahowald et al., 2005; Falkowski et al., 1998;

Published by Copernicus Publications on behalf of the European Geosciences Union. 
Ridgwell, 2009; Meskhidze et al., 2005; Moore et al., 2009). Furthermore, increased dust Fe supply to the global ocean was suggested to be an important factor in reducing atmospheric $\mathrm{CO}_{2}$ during the last glacial maximum (Sigman and Boyle, 2000; Röthlisberger et al., 2004).

While the importance of atmospheric dust in the Fe supply to the oceans is now recognized, the quantification of the flux of bioavailable $\mathrm{Fe}$ from mineral dust remains one of the major uncertainties in the global Fe cycle (Jickells et al., 2005; Mahowald et al., 2005). Since the Fe bioavailability cannot be directly measured chemically, it is generally assumed that the dissolved $\mathrm{Fe}$ in the dust aerosol is bioavailable. The flux of the dissolved Fe can be calculated as

Flux $_{\text {dissolved Fe }}=$ Flux $_{\text {dust }} \times$ FeT $\times$ FS-Fe,

in which FeT is the total Fe content and FS-Fe is the fractional solubility of $\mathrm{Fe}$ (percentage of dissolved to $\mathrm{FeT}$ ). While the estimated total flux of dust to the ocean and FeT in the dust are less uncertain (Jickells et al., 2005; Mahowald et al., 2005; Guieu et al., 2002), the FS-Fe term varies considerably from $\sim 0.1 \%$ to more than $80 \%$, with higher solubility values generally observed when dust mass concentrations are low both over remote parts of the oceans and over polluted areas (e.g., Hand et al., 2004; Chen and Siefert, 2004; Baker and Jickells, 2006; Sedwick et al., 2007; Mahowald et al., 2005; Kumar et al., 2010; Erel et al., 1993; Sedlak et al., 1997; Theodosi et al., 2010). Baker and Jickells (2006) and Measures et al. (2010) also found a similar inverse relationship between dust mass concentration and fractional solubility of $\mathrm{Al}$ (FS-Al) in aerosol samples.

Several hypotheses have been proposed to explain the systematic trends in $\mathrm{Fe}$ and $\mathrm{Al}$ solubility with dust mass concentrations. One hypothesis is the physical sorting idea proposed by Baker and Jickells (2006). They suggested that gravitational settling of coarse dust particles (having lower Fe solubility) across the Atlantic away from the Saharan source could lead to the observed inverse relationship. They argued that the greater solubility at lower dust mass concentrations could be due to a larger surface area to volume ratio of the finer dust particles.

Motivated by the "physical sorting hypothesis", two groups have investigated the size distribution of Fe solubility in atmospheric aerosol. Ooki et al. (2009) reported a higher Fe solubility in finer aerosol collected in Japan during a dust event. In contrast, Buck et al. (2010a) did not find an increasing trend in Fe solubility with the size of aerosol over the northwest Pacific Ocean. Therefore, the effect of physical size sorting on the FS-Fe is still not clear. A major reason is that the dust aerosol collected on cruises or at ground stations may have been subjected to other processes such as mixing with anthropogenic particles and chemical processing which may also alter the FS-Fe (e.g., Baker and Croot, 2010; Sedwick et al., 2007; Chuang et al., 2005; Hsu et al., 2010; Buck et al., 2010b; Measures et al., 2010).
In this study, we have investigated the "physical sorting hypothesis" by combining laboratory experiments of dust precursors with global aerosol simulations. We firstly separated soil samples from two well-known Saharan dust source regions, which have not been atmospherically processed, into 10 aerodynamic diameter $(D)$ size ranges $(0-100 \mu \mathrm{m})$ and measured the FS-Fe and FS-Al of each size fraction. The measured FS-Fe data were combined with outputs from a global aerosol model to evaluate how the process of physical size sorting alone would affect FS-Fe of dust aerosol. The results were then compared with field data to determine the relative importance of physical sorting to explain the observed increase in FS-Fe with decreasing dust mass concentration.

\section{Methodology}

\subsection{Sample description}

The first sample used was a palaeosol from a region of the Western Sahara that has been shown to be a major source of dust by TOMS (Prospero et al., 2002). The second sample was collected from a river channel that drained the Tibesti Mountains in south Libya during the early Holocene humid period and now forms a flash flood water course that is subject to deflation. The area where this sample was collected is also known to be a major Saharan dust source (Prospero et al., 2002; Schepanski et al., 2007). The dithionite Fe (crystalline $\mathrm{Fe}(\mathrm{III})$ oxides, mainly goethite and hematite, which can be extracted by citrate buffered dithionite solution; Shi et al. (2011a, b)) to total Fe ratio, which is a major parameter for Fe mineralogical compositions in the dust (Formenti et al., 2010) and is dependent on the degree of chemical weathering of the source materials (Shi et al., 2011a), in the $D<20 \mu \mathrm{m}$ size fractions of the Western Sahara and Tibesti samples were 0.33 and 0.38 , respectively. These are close to ratios reported in airborne Saharan dust, which is usually between 0.3-0.4 (Lazaro et al., 2008; Lafon et al., 2004; Formenti et al., 2008). This comparison suggests that the $\mathrm{Fe}$ mineralogical compositions of the soil samples are similar to that of the airborne Saharan dust. Therefore, we suggest that the soil samples used in this study are representative of the source materials of atmospheric Saharan dust (Shi et al., 2011a, b), before they are affected by atmospheric processing.

\subsection{Dust size separation}

A Dust Tower (X78502, Grimm Aerosol Technik, Germany) was used to re-suspend the Saharan soil samples (Fig. 1). A compressed air supply driving the dust tower was ultracleaned by three Whatman In-Line Vacuum Protection Filters (WZ-29708-00 Activated Carbon, WZ-29708-02 Desiccant, and WZ-29708-04 Molecular Sieve) and then a HEPA filter. The ultra-clean air was injected into the bottom of the dust tower at $101 \mathrm{~min}^{-1}$ to create a turbulent circulation 


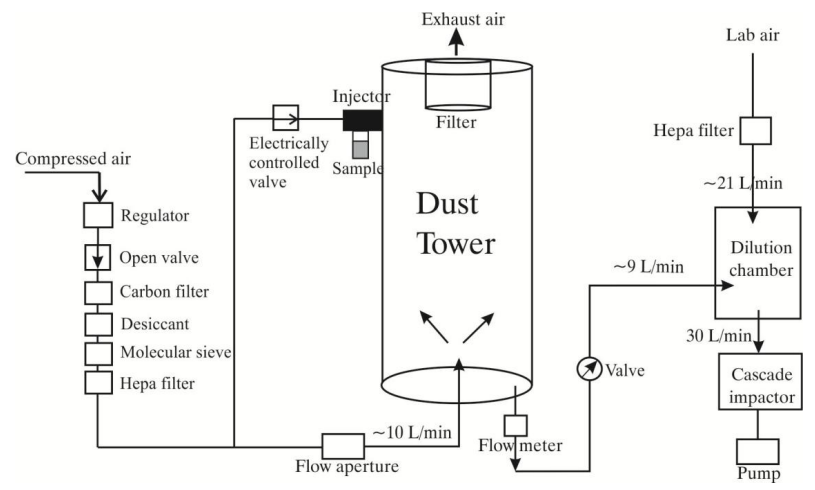

Fig. 1. Sketch diagram of the particle re-suspension and collection system.

within the main body of the tower. A sample was drawn out of this region via sample lines at the tower base while the soil sample to be re-suspended was introduced by placing it into a holding chamber then exposing it to short (approximately $1 \mathrm{~s}$ ) periods of compressed air, thus "blowing" it into the main body of the chamber.

Size separation of the dust sample was performed using an 8-stage Micro Orifice Uniform Deposition Impactor (MOUDI 100, MSP Corporation, USA) which has a $301 \mathrm{~min}^{-1}$ sample flow. This $301 \mathrm{~min}^{-1}$ cannot be drawn in entirely from the dust tower as the flow into the dust tower is only $101 \mathrm{~min}^{-1}$ hence it was made up of a $\sim 91 \mathrm{~min}^{-1}$ flow drawn from the tower with the remainder being made up of HEPA filter-cleaned lab air: mixing of these two lines occurred in the plenum (dilution) chamber immediately preceding the MOUDI.

Before sample re-suspension and size separation were performed, the dust tower was flushed with cleaned compressed air for half an hour in order to ensure an initial particle free environment within the tower. A Condensation Particle Counter (CPC, TSI 3025 A) measuring particle concentrations for $D>6 \mathrm{~nm}$ temporarily replaced the MOUDI and when the particle concentration measured by this instrument was zero the system was considered clean.

An initial set of "treated blank filters" were collected with the MOUDI. The duration of the blank sample collection was $2.5 \mathrm{~h}$ (without soil sample being introduced). After treated blank filter collection, the CPC was reconnected and zero particle concentration confirmed. The soil sample was then placed into the sample injector and introduced into the main body of the dust tower. In order to maintain a sufficient dust loading a dust sample was injected automatically every $8 \mathrm{~s}$. Dust particles were collected on Teflon filters, the cutoff diameter for stages 0 to 8 of the MOUDI were $18 \mu \mathrm{m}, 10 \mu \mathrm{m}$, $5.6 \mu \mathrm{m}, 3.2 \mu \mathrm{m}, 1.8 \mu \mathrm{m}, 1 \mu \mathrm{m}, 0.56 \mu \mathrm{m}, 0.32 \mu \mathrm{m}$, and $0.18 \mu \mathrm{m}$ respectively: a final output filter collected particles less than $0.18 \mu \mathrm{m}$.

\subsection{Dissolved Fe and Al extraction, sample digestion, and trace metal analyses}

The subsequent handling of dissolved $\mathrm{Fe}$ and $\mathrm{Al}$ extractions was carried out using trace metal clean techniques in a Class 100 laboratory. Each filter sample or treated blank filter was cut in half with acid-washed, ceramic-bladed scissors. One part was used for extractions with the filter treated with a $10 \mathrm{ml}$ ammonium acetate solution buffered at $\mathrm{pH} 4.7$ for $\sim 2 \mathrm{~h}$ (as detailed in Baker and Jickells, 2006). Subsequently, the solution was filtered $(0.2 \mu \mathrm{m}$, Teflon syringe filter) and acidified with ultra-pure concentrated $\mathrm{HNO}_{3}$ to $0.4 \% \mathrm{v} / \mathrm{v} \mathrm{HNO}_{3}$. Ultrapure ammonia solution (TraceSELECT) and doubledistilled acetic acid were used to make the ammonium acetate solution. Once prepared, the solutions were stored in a refrigerator until the analysis was performed.

The other half of the filter was digested in an ultra-clean Teflon bomb with a mixture of ultrapure $\mathrm{HF}$ and double distilled $\mathrm{HNO}_{3}$ (3:1) acid at $\sim 120^{\circ} \mathrm{C}$ for $24 \mathrm{~h}$. The $\mathrm{HF} / \mathrm{HNO}_{3}$ mix was then evaporated at $\sim 90^{\circ} \mathrm{C}$. The dry residue was re-digested in concentrated and double-distilled $\mathrm{HNO}_{3}$ at $\sim 90^{\circ} \mathrm{C}$ in the Teflon bomb for $\sim 15 \mathrm{~h}$ and evaporated to dryness. The residue was treated with concentrated and double distilled $\mathrm{HCl}$, again in the Teflon bomb, for $\sim 15 \mathrm{~h}$ and evaporated at $\sim 120^{\circ} \mathrm{C}$ to complete dryness. The final residue was dissolved in $1 \mathrm{M} \mathrm{HNO}_{3}$ (diluted from double-distilled concentrated $\mathrm{HNO}_{3}$ with ultrapure $18 \mathrm{M} \Omega \mathrm{H}_{2} \mathrm{O}$ ) at $\sim 80^{\circ} \mathrm{C}$ for $\sim 15 \mathrm{~h}$. All sample digestions were performed in the University of Leeds Geochronology (TIMS) laboratory in clean and dedicated fume hoods.

The elemental concentrations of both $\mathrm{Al}$ and $\mathrm{Fe}$ in the dissolved and total phases were measured using an Inductively Coupled Plasma-Mass Spectrometer (ICP-MS). The analysis was undertaken at the University of Portsmouth in the ISO9001 accredited analytical facilities using an Agilent 7500ce ICP-MS and an integrated auto-sampler (I-AS). The 7500 ce uses an octopole reaction system to eliminate any spectral interference (Planquette et al., 2009). The reaction system can be run in two modes; reaction mode using hydrogen gas which was used for the analysis of $\mathrm{Fe}^{56}$ and collision mode using helium gas which was used for the analysis of $\mathrm{Al}^{27}$. The use of the octopole reaction system eliminates any polyatomic spectral interferences and the need for interference corrections.

A dilution factor of 2-100 (depending on dissolved or total) was applied to each sample. The data processing procedure used the Agilent software Chemstation and included linear drift correction, blank subtraction, calibration, and a dilution correction. For this work, mixed standards were prepared in the range of 0.1 to $500 \mu \mathrm{g} \mathrm{l}^{-1}$ in $2 \%$ nitric \& $0.5 \%$ hydrochloric solution. An internal standard of $20 \mu \mathrm{g} \mathrm{l}^{-1} \mathrm{Rh}$ (stock solution of $400 \mu \mathrm{g} \mathrm{l}^{-1} \mathrm{Rh}$ with twenty fold online dilution) was used to determine any variation in the intensity of the signal. This correction is made automatically by the software. The instrument detection limits were 0.05 and 
Table 1. Average concentration and standard deviation of the $\mathrm{Fe}$ and $\mathrm{Al}$ concentrations (unit: $\mu \mathrm{g} \mathrm{f}^{-1}$ ) in the extraction solutions (ammonium acetate and $1 \mathrm{M} \mathrm{HNO}_{3}$ ), new filter blanks, and "treated filter blanks" measured using ICP-MS.

\begin{tabular}{lccccr}
\hline & \multicolumn{3}{c}{ Average \pm standard deviation } & \multirow{2}{*}{ Number of replicates } \\
\cline { 2 - 4 } & Dissolved Fe & Total Fe & Dissolved Al & Total Al nn \\
\hline Solution & $0.7 \pm 0.3$ & $1.9 \pm 0.6$ & $1.5 \pm 1.0$ & $6.4 \pm 0.3$ & 4 \\
New filter & $0.7 \pm 0.3$ & $92 \pm 19$ & $1.2 \pm 1.2$ & $29 \pm 7$ & 6 \\
Treated filter & $0.7 \pm 0.5$ & $115 \pm 17$ & $0.7 \pm 0.4$ & $33 \pm 17$ & 10 \\
\hline
\end{tabular}

$0.02 \mu \mathrm{gl}^{-1}$ for $\mathrm{Al}$ and $\mathrm{Fe}$, respectively. $\mathrm{FeT}$ was also measured by the ferrozine method (Viollier et al., 2000). There was less than $10 \%$ difference in the measured FeT concentrations by the ferrozine method and the ICP-MS. The data presented here is that from the ICP-MS. The precision of the ferrozine method was $\pm 1.2 \% \quad(1 \sigma, n=6)$ (Shi et al., 2011a), while the precision of the ICP-MS Fe technique was $\pm 2.3 \%(1 \sigma, n=6)$ using the CRM SLRS-4. In addition, to verify the efficacy of the total trace metal digestion, the FeT in the Tibesti-PM $\mathrm{PM}_{20}$ and Western Sahara-PM 20 samples was compared with total $\mathrm{Fe}$ determined by X-ray Fluorescence (XRF) (Shi et al., 2011b). FeT in these two samples was $4.6 \%$ and $4.4 \%$, similar to $4.8 \%$ and $4.7 \%$ measured by XRF (Shi et al., 2011a, b). To test the blank trace metal concentrations, six new blank filters (different from the aforementioned "treated blank filters") were treated following the same procedure as the other blanks and samples. Fe and $\mathrm{Al}$ concentrations were $0.7 \pm 0.3 \mu \mathrm{g} \mathrm{l}^{-1}(1 \sigma$, $n=4)$ and $1.5 \pm 1.0 \mu \mathrm{g} \mathrm{l}^{-1}(1 \sigma, n=4)$ in the ammonium acetate solution used for extraction, $0.7 \pm 0.3 \mu \mathrm{g}{ }^{-1}(1 \sigma, n=6)$ and $1.2 \pm 1.2 \mu \mathrm{gl}^{-1}(1 \sigma, n=6)$ in the new blank filters, and $0.7 \pm 0.5 \mu \mathrm{g}^{-1}(1 \sigma, n=10)$ and $0.7 \pm 0.4 \mu \mathrm{g} 1^{-1}(1 \sigma$, $n=10$ ) in the "treated blank filters" (Table 1). The average dissolved $\mathrm{Fe}$ and $\mathrm{Al}$ concentrations in the "treated blank filters" were similar to those of the new blank filters and the ammonium acetate extract, suggesting that there were no contaminating particles in the dust-generation system.

The $\mathrm{Fe}$ and $\mathrm{Al}$ concentrations were $1.9 \pm 0.6 \mu \mathrm{g} \mathrm{l}^{-1}(1 \sigma$, $n=4)$ and $6.4 \pm 0.3 \mu \mathrm{g} \mathrm{l}^{-1}(1 \sigma, n=4)$ in the $1 \mathrm{M} \mathrm{HNO}_{3}$ used for digestion, $92 \pm 19 \mu \mathrm{gl}^{-1}(1 \sigma, n=6)$ and $29 \pm 7 \mu \mathrm{g} \mathrm{l^{-1 }}$ $(1 \sigma, n=6)$ in the new blank filters, and $115 \pm 17 \mu \mathrm{gl}^{-1}(1 \sigma$, $n=10)$ and $33 \pm 17 \mu \mathrm{gl}^{-1}(1 \sigma, n=10)$ in the "treated blank filters" (Table 1). Therefore, there is only a slight increase in the FeT concentrations in the treated blank filters, which is probably due to the sample digestion processes involved (repeated evaporation and digestion). The average blank $\mathrm{Fe}$ and $\mathrm{Al}$ concentrations were subtracted from the measured values in the sample solutions. Fractional $\mathrm{Fe}$ and $\mathrm{Al}$ solubilities (FS$\mathrm{Fe}$ and $\mathrm{FS}-\mathrm{Al}$ ) were calculated as the percentage of dissolved to total $\mathrm{Fe}$ or $\mathrm{Al}$, respectively.

\subsection{Model description}

The Global Model of Aerosol Processes (GLOMAP, Spracklen et al., 2005; Manktelow et al., 2007, 2010; Merikanto et al., 2010) is a detailed size-resolving aerosol microphysics model, running within the TOMCAT chemical transport model (Chipperfield, 2006). The model is driven by European Centre for Medium-range Weather Forecasts ERA-40 reanalysis meteorology (Uppala et al., 2005). The version of GLOMAP used here, known as GLOMAP-bin, has a sectional representation of the aerosol size distribution with 20 bins, and contains emissions of dust, sea-spray, sulphur species, and elemental and organic carbon. Dust is carried in the largest 12 bins (diameter from $\sim 0.1 \mu \mathrm{m}$ to $>10 \mu \mathrm{m})$. The microphysical processes parameterized in the model are nucleation, condensation, coagulation, aqueousphase oxidation, and dry and wet deposition. In the simulations presented here, AeroCom daily varying dust emissions are prescribed (Dentener et al., 2006). The dust is assumed to be non-hygroscopic at emission but becomes hygroscopic through coagulation with other water-soluble aerosol and by uptake of condensable vapours (e.g. sulphuric acid). Only the hygroscopic dust particles are removed by wet scavenging processes, while both hygroscopic and non-hygroscopic particles are dry deposited. Sedimentation of dust particles is calculated separately for each of the 12 size classes, assuming a density of $2650 \mathrm{~kg} \mathrm{~m}^{-3}$. The sedimentation and dry deposition scheme is that of Zhang et al. (2001), and accounts for particle size, surface type and wind speed effects.

In order to assess how FS-Fe of dust aerosol evolves as a result of physical processing (i.e. the preferential removal of larger dust particles), the modelled size-resolved mass concentrations from GLOMAP-bin were combined with the measured FS-Fe data. The model output was 'sampled' from an area over the tropical to subtropical North Atlantic ocean, spanning $0^{\circ} \mathrm{W}$ to $85^{\circ} \mathrm{W}$, and $0^{\circ} \mathrm{N}$ to $32^{\circ} \mathrm{N}$, corresponding to a major dust pathway from the Sahara. A model-based estimate of FS-Fe was derived assuming an $\mathrm{FeT}$ of $4.5 \%$, which is the average of the Western Sahara and Tibesti samples. The FeT used here is slightly higher than those used in other modelling studies (Hand et al., 2004; Meskhidze et al., 2005; Fan et al., 2006; Solmon et al., 2009; Ito and 
Table 2. As measured dissolved $\mathrm{Fe}(\mathrm{D}-\mathrm{Fe})$, dissolved $\mathrm{Al}(\mathrm{D}-\mathrm{Al})$, total $\mathrm{Fe}(\mathrm{FeT})$, and total $\mathrm{Al}(\mathrm{AlT})$ concentrations (unit: $\left.\mu \mathrm{g} 1^{-1}\right)$, and fractional Fe solubility (FS-Fe) and fractional Al solubility (FS-Al) in the "treated blank filters", Western Sahara and Tibesti samples measured using ICP-MS.

\begin{tabular}{|c|c|c|c|c|c|c|c|c|c|c|c|c|c|c|c|c|c|c|}
\hline \multirow[b]{2}{*}{ size, $\mu \mathrm{m}$} & \multicolumn{4}{|c|}{ Treated blank filter } & \multicolumn{7}{|c|}{ Western Sahara } & \multicolumn{7}{|c|}{ Tibesti } \\
\hline & $\mathrm{D}-\mathrm{Fe}$ & $\mathrm{FeT}$ & D-Al & $\mathrm{AlT}$ & $\mathrm{D}-\mathrm{Fe}$ & $\mathrm{FeT}$ & D-Al & AlT & $\mathrm{FS}-\mathrm{Fe}$ & FS-Al & $\mathrm{FeT} / \mathrm{AlT}$ & $\mathrm{D}-\mathrm{Fe}$ & $\mathrm{FeT}$ & D-Al & AlT & FS-Fe & FS-Al & FeT/AlT \\
\hline $0.32-0.18$ & 0.4 & 107 & 0.7 & 24 & 3.8 & 533 & 13.3 & 914.6 & 0.80 & 1.42 & 0.58 & 3.7 & 890 & 15.1 & 1707 & 0.42 & 0.86 & 0.52 \\
\hline $0.56-0.32$ & 0.7 & 122 & 0.8 & 41 & 18.8 & 4474 & 101.4 & 10632 & 0.42 & 0.95 & 0.42 & 10.5 & 3254 & 54.4 & 7488 & 0.31 & 0.72 & 0.43 \\
\hline $1.0-0.56$ & 1.2 & 97 & 0.2 & 22 & 40.1 & 17572 & 341.8 & 36740 & 0.22 & 0.93 & 0.48 & 13.2 & 5003 & 91.2 & 11926 & 0.24 & 0.76 & 0.42 \\
\hline $1.8-1.0$ & 0.3 & 108 & 0.4 & 33 & 65.0 & 27980 & 450.0 & 59160 & 0.23 & 0.76 & 0.47 & 14.9 & 7636 & 118.1 & 17982 & 0.19 & 0.66 & 0.42 \\
\hline $3.2-1.8$ & 0.5 & 123 & 0.7 & 28 & 42.0 & 41040 & 557.0 & 86260 & 0.10 & 0.65 & 0.48 & 12.0 & 5666 & 77.2 & 12756 & 0.21 & 0.60 & 0.44 \\
\hline $5.6-3.2$ & 0.9 & 139 & 0.2 & 25 & 37.4 & 34960 & 437.4 & 73840 & 0.10 & 0.59 & 0.47 & 4.2 & 1270 & 18.0 & 2458 & 0.29 & 0.73 & 0.52 \\
\hline $10-5.6$ & 1.8 & 112 & 0.4 & 34 & 13.8 & 6870 & 90.6 & 15900 & 0.18 & 0.57 & 0.43 & $<\mathrm{DL}$ & $<\mathrm{DL}$ & $<\mathrm{DL}$ & $<\mathrm{DL}$ & $<\mathrm{DL}$ & $<\mathrm{DL}$ & $<$ DL \\
\hline $18-10$ & 0.3 & 98 & 0.8 & 25 & 6.2 & 2868 & 31.2 & 5452 & 0.21 & 0.56 & 0.53 & $<\mathrm{DL}$ & $<\mathrm{DL}$ & $<\mathrm{DL}$ & $<\mathrm{DL}$ & $<\mathrm{DL}$ & $<\mathrm{DL}$ & $<$ DL \\
\hline$>18$ & 0.3 & 98 & 0.8 & 24 & 11.4 & 5948 & 65.5 & 13916 & 0.19 & 0.47 & 0.43 & $<\mathrm{DL}$ & $<\mathrm{DL}$ & $<\mathrm{DL}$ & $<\mathrm{DL}$ & $<\mathrm{DL}$ & $<\mathrm{DL}$ & $<$ DL \\
\hline
\end{tabular}

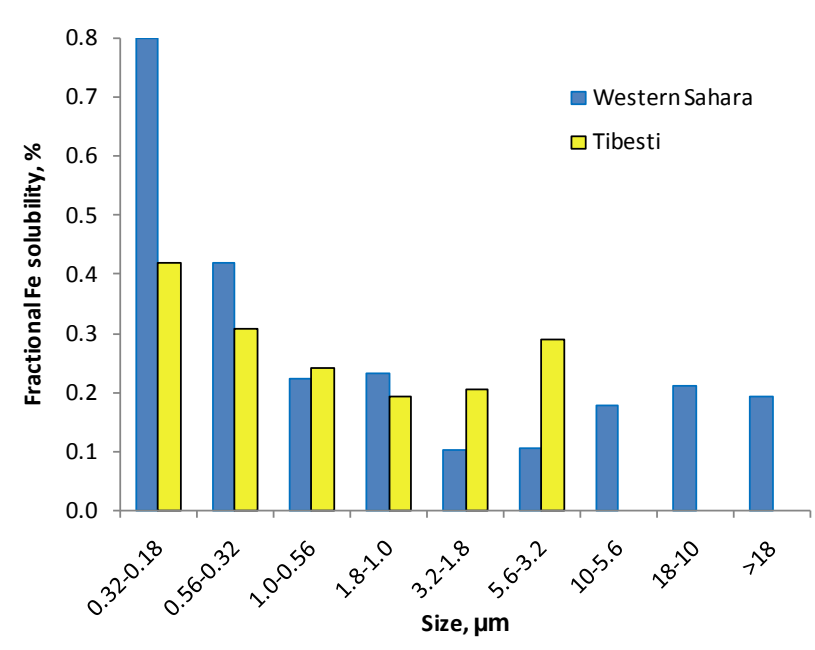

Fig. 2. Fractional Fe solubility (FS-Fe) of size-fractionated dust generated from the Western Sahara and Tibesti samples.

Feng, 2010). The size-resolved FS-Fe data are mapped on to the size ranges of the 12 GLOMAP dust bins using linear interpolation. FS-Fe of dust aerosol (across the whole size range) in each gridbox was then calculated by multiplying the dust mass concentration in each GLOMAP size bin by FeT $(4.5 \%)$ and the measured FS-Fe. The model data presented in this paper is a three-month (January-March 2000) mean, following three months of spin-up from a zero-aerosol atmosphere.

\section{Results and discussions}

\subsection{Size distribution of FS-Fe and FS-Al in mineral dust}

Table 2 lists the measured dissolved and total $\mathrm{Fe}$ and $\mathrm{Al}$ concentrations in the size-fractionated dust from both the Western Sahara and Tibesti samples. Dissolved and/or FeT and total $\mathrm{Al}(\mathrm{AlT})$ in the $>18 \mu \mathrm{m}, 18-10 \mu \mathrm{m}$, and $10-5.6 \mu \mathrm{m}$ size fractions from the Tibesti sample and the $<0.18 \mu \mathrm{m}$ fractions from both the Tibesti and Western Sahara samples were not included in the table since they were below the limit of detection. Table 2 also illustrates that FeT/AIT in the samples ranges from 0.42 to 0.58 and from 0.42 to 0.52 in the Western Sahara and Tibesti samples. These values are close to those reported in the $<20 \mu \mathrm{m}$ fractions in the two soil samples (Shi et al., 2011a).

Fig. 2 shows the size distribution of the FS-Fe in the dust generated from the Western Sahara and Tibesti samples. FS-Fe in the dust from the Western Sahara sample ranged from $\sim 0.1 \%$ in the 5.6-3.2 $\mu \mathrm{m}$ and $3.2-1.8 \mu \mathrm{m}$ fractions to $\sim 0.8 \%$ in $0.32-0.18 \mu \mathrm{m}$ fractions. The FS-Fe in the dust $(5.6-0.18 \mu \mathrm{m})$ generated from the Tibesti sample shows smaller variations from $\sim 0.2 \%$ in the $1.8-1.0 \mu \mathrm{m}$ fraction to $\sim 0.4 \%$ in $0.32-0.18 \mu \mathrm{m}$ fraction. Therefore, the FS-Fe in the dust generated from both soil samples has some degree of size dependence, with finer particles $(<1 \mu \mathrm{m})$ having a higher FS-Fe.

The FS-Al shows a similar size dependence to that of $\mathrm{Fe}$ (Fig. 3), with higher FS-Al observed in the 0.18-0.32 $\mu \mathrm{m}$ size fractions, especially for the Western Sahara sample. The average ratio of FS-Fe/FS-Al in each size bin is $3.3 \pm 1.8(1 \sigma$, $n=9)$ from the Western Sahara sample and $2.7 \pm 0.5(1 \sigma$, $n=6$ ) from the Tibesti sample.

The higher Fe and Al solubility in sub-micrometer size particles appears to be compatible with the hypothesis of Baker and Jickells (2006) that the higher surface area to volume ratio of smaller dust particles leads to higher proportions of their total $\mathrm{Fe}$ and $\mathrm{Al}$ content being available for dissolution. However, FS-Fe and FS-Al increase by only a factor of two to three times from $>10 \mu \mathrm{m}$ to $0.32-0.18$ size fractions in the Western Sahara and Tibesti samples (Figs. 2 and 3). There are at least two potential reasons for such a small difference in the FS-Fe and FS-Al in larger dust particles of different sizes. One is related to the surface roughness of the large dust particles. Under idealized conditions, surface to 


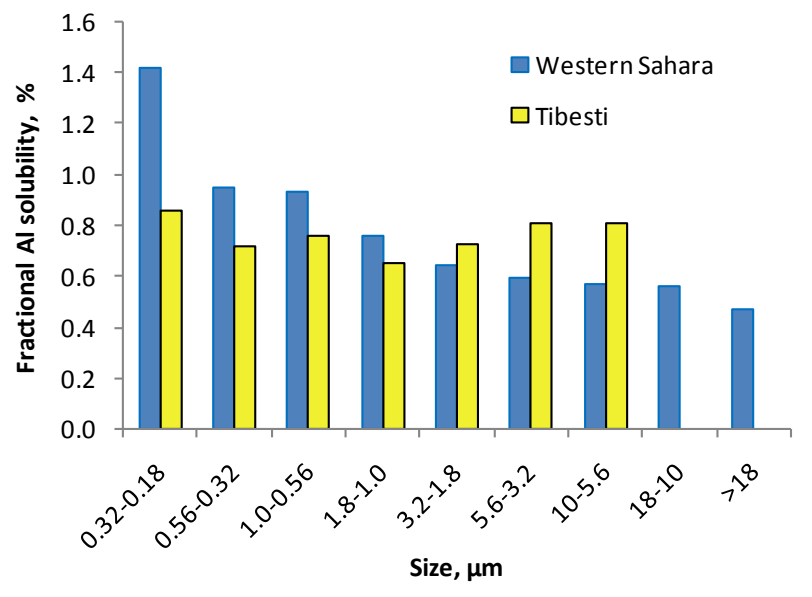

Fig. 3. Fractional Al solubility (FS-Al) of size-fractionated dust generated from Western Sahara and Tibesti samples.

volume ratio is inversely proportional to the particle size assuming each particle is spherical and smooth. But dust particles are rarely smooth and spherical and have rough surfaces, crevices, and dislocations (e.g., Shi et al., 2003, 2005). In addition, large dust particles are often aggregates of smaller particles (e.g., Shi et al., 2003, 2008). Therefore, surface to volume ratio of the actual dust particles is likely to be less size dependent than idealized spherical particles. Alternatively, although some of the ultra-fine poorly crystalline Fe oxides (Shi et al., 2011a) or the so-called readily released Fe (Mackie et al., 2006) may be separated from the surfaces of larger dust particles and physically re-distributed in the finer size fractions during sand-blasting (Mackie et al., 2006), a large fraction of the readily released Fe may remain on the surface of large dust particles. For example, Shi et al. (2011b) showed that the amount of the most reactive Fe pool per gram of dust increases from $10.5 \mu \mathrm{mol}$ in $\mathrm{PM}_{20}(<20 \mu \mathrm{m})$ to $18 \mu \mathrm{mol}$ in $\mathrm{PM}_{10}(<10 \mu \mathrm{m})$ and $25 \mu \mathrm{mol}$ in $\mathrm{PM}_{2.5}(<2.5 \mu \mathrm{m})$ from the Tibesti sample. Thus, the most reactive $\mathrm{Fe}$ pool is only slightly higher in the $<2.5 \mu \mathrm{m}$ compared to the $<10 \mu \mathrm{m}$ fractions of dust particles.

Our data showed that even the maximum FS-Fe and FS$\mathrm{Al}$ in the finest size fraction $(0.18-0.32 \mu \mathrm{m})$ observed in this study (Fe: $\sim 0.8 \%$; Al: $1.42 \%$ ) is lower than most of the measured values in airborne aerosol samples previously reported (e.g., Chen and Siefert, 2004; Baker and Jickells, 2006). The FS-Fe observed in the size-fractionated dust particles in the current study range from $0.1-0.8 \%$ and are of a similar magnitude to those measured in the original mineral dust (e.g., Desboeufs et al., 1999; Chuang et al., 2005; Paris et al., 2010; Schroth et al., 2009). Ooki et al. (2009) and Buck et al. (2010a) measured the FS-Fe of size-fractionated atmospheric aerosol. Their values are one to three orders of magnitude higher than those of the non-processed dust of similar size ranges reported in this study. These results in-

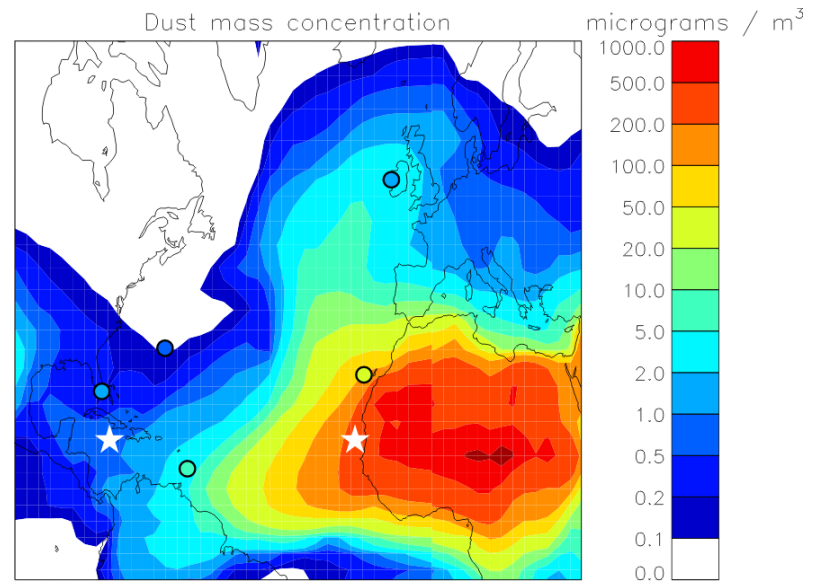

Fig. 4. Three-month mean (January-March) surface dust mass concentrations from the region of interest from GLOMAP-bin, overlaid with equivalent in-situ observations from the University of Miami aerosol network (coloured circles). Stars highlight locations referred to in Fig. 5 and in the text.

dicate that the size dependence of FS-Fe can only explain a small part of the measured variability in FS-Fe observed in atmospheric aerosol samples. The high values of the FS-Fe of $10 \%$ or even $50 \%$ in some size fractions of the aerosol reported in Buck et al. (2010a) and Ooki et al. (2009) are very unlikely to be seen in non-atmospherically processed mineral dust because of the refractory nature of the $\mathrm{Fe}$ in the original dust (Shi et al., 2011a, b).

In the following sections, we combine the aforementioned size-resolved FS-Fe data with the model size-resolved dust mass concentrations from GLOMAP to investigate the potential impact of physical size sorting on FS-Fe in the dust during trans-Atlantic transport. The simulated FS-Fe data are then compared with the field datasets (Baker and Jickells, 2006) under similar dust mass concentrations.

\subsection{Model size-resolved dust mass concentrations}

Surface dust mass concentrations over the Sahara and North Atlantic region calculated in the GLOMAP-bin model for the period January to March 2000 are shown in Fig. 4. For comparison, also shown are in-situ observations from the University of Miami aerosol network (coloured circles), filtered by Woodward (2001). Globally (not shown), GLOMAPbin overestimates dust mass concentrations compared to the Woodward (2001) dataset, with a normalized mean bias (mean of (model-observation)/observation) of 0.30 for the January to March period. For the five observations shown in Fig. 4 (coloured circles), the normalized mean bias is 0.28 , indicating that the model slightly overestimates dust mass concentrations in the region of interest. This comparison illustrates that GLOMAP-bin is capable of representing atmospheric dust mass concentrations near source, and remote 


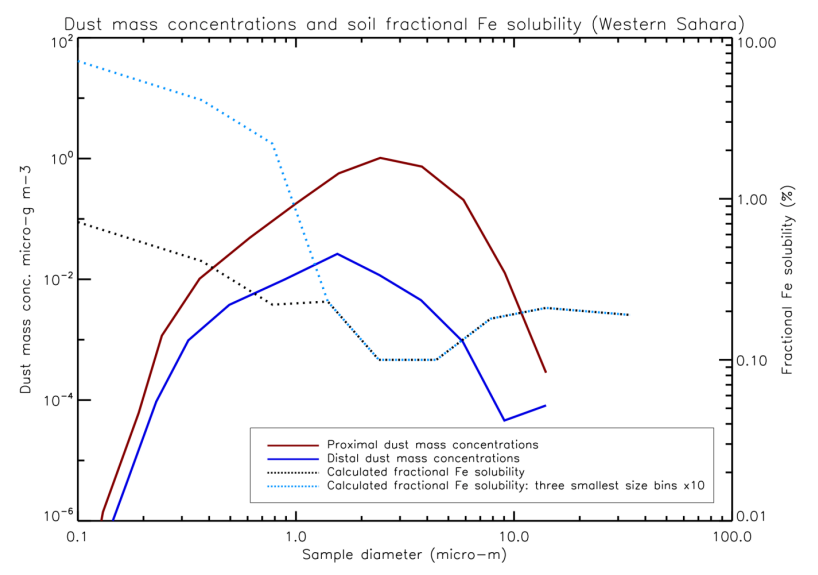

Fig. 5. Modelled dust mass size distributions (left-hand y-axis) from the two gridboxes over the ocean, one proximal to the dust source (burgundy line), and one distal location (dark blue line). The location of these two gridboxes is indicated by white stars in Fig. 4. The black and light blue dotted lines (right-hand y-axis) show the measured size-resolved Fe solubility from the Western Sahara soil sample as compared to the hypothetical curve when the measured FS-Fe from three smallest size bins $(<0.18-0.32 \mu \mathrm{m} ; 0.32-0.56 \mu \mathrm{m}$; and $0.56-1.0 \mu \mathrm{m}$ ) were increased by a factor of ten.

from source region by which time considerable atmospheric processing may have occurred.

Because GLOMAP-bin resolves particle size and microphysical processes, it is capable of simulating the changing size distribution during transport of an aerosol population. The evolution of the size-resolved dust mass concentration from GLOMAP-bin along a west-to-east path across the North Atlantic is shown by the two solid lines in Fig. 5. The near-source size-resolved mass concentrations (location shown by the easternmost white star in Fig. 4) are one to two orders of magnitude larger than those at a more distant gridbox (indicated by the westernmost white star in Fig. 4). The greatest differences between the two locations are for radii greater than $1 \mu \mathrm{m}$. In addition, the peak size of the dust mass concentration shifted from $>1 \mu \mathrm{m}$ at the gridbox close to the dust source region to $<1 \mu \mathrm{m}$ at the distal gridbox, as dust particles at radii larger than $1 \mu \mathrm{m}$ are more rapidly removed by gravitational settling.

\subsection{Testing the physical sorting hypothesis}

Figure 6 shows the modelled FS-Fe at each gridbox against dust mass concentration by combining the laboratory measured FS-Fe (the Western Sahara sample) with the model outputs (i.e., size resolved dust mass concentration). The calculated FS-Fe of dust aerosol increases systematically from $\sim 0.1 \%$ at high dust mass concentrations to $\sim 0.2 \%$ at low concentrations. Also shown in Fig. 6 is a subset of the Baker and Jickells (2006) data covering the same region as the

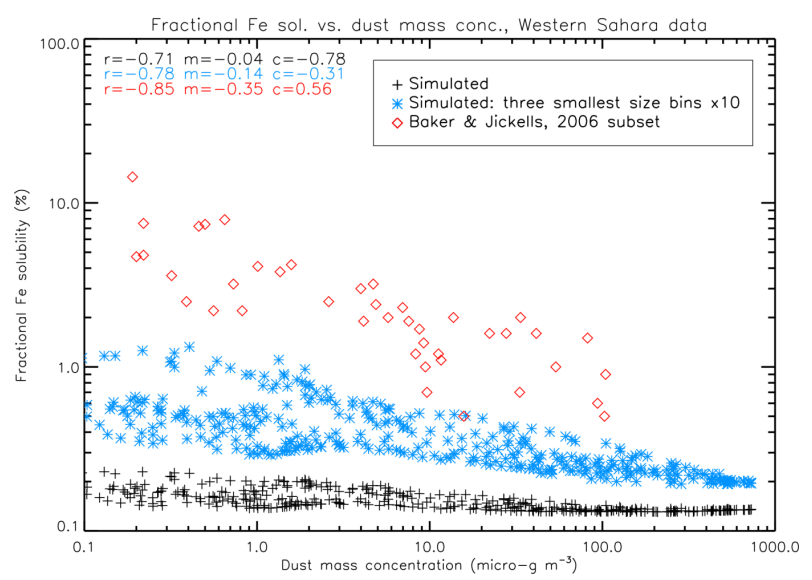

Fig. 6. Variations of fractional Fe solubility (FS-Fe) with dust mass concentration. Red datapoints are a subset of the Baker and Jickells (2006) dataset. Black datapoints are the FS-Fe calculated by combining the measured size-resolved FS-Fe from the Western Sahara sample with GLOMAP outputs (size-resolved dust mass concentrations). Blue datapoints are the FS-Fe calculated in the same way but with the measured FS-Fe of the three smallest size fractions (0.18$0.32 \mu \mathrm{m} ; 0.32-0.56 \mu \mathrm{m}$; and $0.56-1.0 \mu \mathrm{m})$ increased by a factor of ten. Summary statistics at the top left of the figure are discussed in the text.

model sampling area (see Sect. 2.4). The field observations show an increase from less than $1.0 \%$ to greater than $10.0 \%$ across the same range of dust mass concentrations. The calculations based on measured FS-Fe from the Tibesti sample showed an even smaller increase in FS-Fe in the dust during transport (data not shown).

A sensitivity test was conducted by assuming that the FS$\mathrm{Fe}$ at the three smallest sizes $(1.0-0.56 \mu \mathrm{m}, 0.56-0.32 \mu \mathrm{m}$, and $0.32-0.18 \mu \mathrm{m}$ ) were ten times higher than the measured values from the Western Sahara sample (dotted light blue line in Fig. 5). The resultant simulated FS-Fe is shown in Fig. 6 as blue datapoints. Increasing the contrast in FS-Fe between small and large dust particles accentuates the role of physical processing. However, even with this hypothetical FS-Fe size distribution, the calculated FS-Fe of dust aerosol increased from $\sim 0.1 \%$ at high dust concentrations to only $\sim 1.0 \%$ at low concentrations. The latter is still an order of magnitude lower than those measured in the field (Fig. 6).

The relationship between the three sets of datapoints in Fig. 6 has been quantified by fitting the data with a line of the form:

$\log (\mathrm{FS}-\mathrm{Fe})=m \times \log ($ dust mass concentration $)+c$

in which $m$ is the gradient and $c$ is the intercept. The gradient $m$ of the line calculated from the combined soil FS-Fe and GLOMAP data (black datapoints in Fig. 6) was -0.04, which is only about one tenth of the gradient $(-0.35)$ calculated from the subset of the Baker and Jickells (2006) data. The 
Pearson correlation coefficient $r$ was also calculated. The $r$ values are all greater than 0.70 , suggesting the correlations are robust. Even when the hypothetical relationship between size and FS-Fe is used (blue datapoints in Fig. 6), the gradient of the fitted line is only -0.14 , about one third of that derived from the atmospheric aerosol samples.

The large contrast in gradients between the simulated and measured FS-Fe indicates that the observed increase in FS-Fe with decreasing dust mass concentration observed in Baker and Jickells (2006) cannot be explained solely by the physical size sorting process. Similarly (data not shown here), the observed FS-Al with decreasing dust mass concentration reported in Baker and Jickells (2006) and Measures et al. (2010) also cannot be explained by the physical size sorting process only.

These results suggest that the observed increase in FS-Fe with trans-Atlantic transport (decreasing mass concentration) in Baker and Jickells (2006) occurs mainly as a result of additional mechanisms. One possible mechanism is the mixing of dust aerosol with combustion particles with higher FS-Fe (e.g., Chuang et al., 2005; Desboeufs et al., 2005; Sedwick et al., 2007; Luo et al., 2008; Sholkovitz et al., 2009; Kumar et al., 2010; Hsu et al., 2010). Another mechanism is chemical processing of the dust, including acid mobilization (Hand et al., 2004; Zhu et al., 1992; Meskhidze et al., 2003, 2005; Fan et al., 2006; Solmon et al., 2009; Ito and Feng, 2010; Measures et al., 2010; Shi et al., 2011a) and photo-reduction (e.g., Zhu et al., 1997; Spokes and Jickells, 1996; Hand et al., 2004).

During dust transport, larger dust particles deposit preferentially due to faster gravitational settling leading to a shift in mass size distribution (Fig. 5). Our results suggest that the shift alone cannot explain the inverse relationship between FS-Fe and dust mass concentrations reported in Baker and Jickells (2006). However, it is useful to recognize that during long-range transport, the shift in size will also likely be accompanied by relevant changes which include: (1) increase in the content of more reactive Fe per mass of dust (Shi et al., 2011b); (2) increase in surface area (Baker and Jickells, 2006); and (3) reduced neutralizing capacity (less carbonate in the atmosphere) and increased potential for acid processing and photo-reduction (Spokes and Jickells, 1996). All these processes could potentially lead to an enhanced FS-Fe in dust aerosols.

Finally, although the two soil samples are representative of Saharan dust, there are some variations in mineralogical and chemical properties of dust from other regions of $\mathrm{N}$ Africa such as the Sahel (Shi et al., 2011a; Lazaro et al., 2008; Formenti et al., 2008). Such variation may slightly change the slope of the modelled FS-Fe with dust mass concentration shown in Fig. 6. The slope may also be to some extent affected by the outputs of size-resolved mass distribution using different global models. However, these limitations will unlikely change our conclusion that physical size sorting is not the dominant process causing the observed inverse re- lationship between FS-Fe and atmospheric dust mass concentration, as evidenced by the sensitivity test (Fig. 6, blue datapoints).

\section{Conclusions}

In this study, we report the size-resolved FS-Fe and FS-Al using mineral dust precursors which have not been subjected to atmospheric processing. Our data showed that the FS-Fe ranges from $\sim 0.1$ to $0.8 \%$ and that of $\mathrm{Al}$ ranged from $0.5 \%$ to $1.4 \%$. The measured FS-Fe in size-fractionated dust particles from the soil samples is orders of magnitude lower than those of the atmospheric aerosol samples of similar size reported in literature. We find a similar size dependence between the FS-Fe and FS-Al, with the finest $(0.18-0.32 \mu \mathrm{m})$ dust particles having the highest values. By combining the size-resolved FS-Fe from soil dust samples with the sizeresolved dust mass concentrations from a detailed microphysical model, we show that physical sorting leads to a systematic increase in FS-Fe in the dust. However, the magnitude of the increase in FS-Fe with decreasing dust mass concentrations due to physical sorting is nearly an order of magnitude lower than that observed over the tropical and subtropical Atlantic Ocean by Baker and Jickells (2006). This suggests that once the dust reaches the Atlantic Ocean, physical size sorting is not the dominant mechanism causing the enhancement of the FS-Fe in dust aerosol during transport. We therefore suggest that processes such as chemical reactions on the dust particles and/or mixing with anthropogenic particles are the dominant causes of changes in fractional $\mathrm{Fe}$ solubility in transported dust.

Acknowledgements. This work was supported by the Natural Environment Research Council grants NER/S/R/2006/14283 (M. Woodhouse), NE/E011470/1 (M. Krom) and NE/F017359/1 (T. Jickells), R8/H12/124 (QUEST-Dust: K. Carslaw), and the APPRAISE project (K. Carslaw). G.W. Mann was supported by the National Centre for Atmospheric Science.

Edited by: A. Nenes

\section{References}

Baker, A. R. and Jickells, T. D.: Mineral particle size as a control on aerosol iron solubility, Geophys. Res. Lett., 33, L17608, doi:10.1029/2006GL026557, 2006.

Baker, A. R. and Croot, P. L.: Atmospheric and marine controls on aerosol iron solubility in seawater, Mar. Chem., 120, 4-13, 2010.

Boyd, P. W. and Ellwood, M. J.: The biogeochemical cycle of iron in the ocean, Nature Geosci., 3, 675-682, doi:10.1038/ngeo964, 2010.

Boyd, P., Jickells, T. D., Law, C. S., Blain, S., Boyle, E. A., Buesseler, K. O., Coale, K. H., Cullen, J. J., de Baar, H. J. W., Follows, M., Harvey, M., Lancelot, C., Levasseu, M., Owens, N. P. J., Pollard, R., Rivkin, R. B., Sarmiento, J., Schoemann, V., Smetacek, V., Takeda, S., Tsuda, A., Turner, S., and Watson, A. 
J.: Mesoscale iron enrichment experiments 1993-2005: synthesis and future directions, Science, 315, 612-617, 2007.

Buck, C. S., Landing, W. M., and Resing, J. A.: Particle size and aerosol iron solubility: a high resolution analysis of Atlantic aerosols, Mar. Chem., 120, 14-24, doi:10.1016/j.marchem.2008.11.002, 2010a.

Buck, C. S., Lang, W. M., Resing, J. A., and Measures, C. I.: The solubility and deposition of aerosol $\mathrm{Fe}$ and other trace elements in the North Atlantic Ocean: Observations from the A16N CLIVAR/CO2 repeat hydrography section, Mar. Chem., 120, 57-70, doi:10.1016/j.marchem.2008.08.003, 2010b.

Chen, Y. and Siefert, R. L.: Seasonal and spatial distributions and dry deposition fluxes of atmospheric total and labile iron over the tropical and subtropical North Atlantic Ocean, J. Geophys. Res., 109, D09305, doi:10.1029/2003JD003958, 2004.

Chipperfield, M. P.: New Version of the TOMCAT/SLIMCAT OffLine Chemical Transport Model: Intercomparison of Stratospheric Tracer Experiments, Q. J. R. Meteorol. Soc., 132, 11791203, doi:10.1256/qj.05.51, 2006.

Chuang, P. Y., Duvall, R. M., Shafer, M. M., and Schauer, J. J.: The origin of water soluble particulate iron in the Asian atmospheric outflow, Geophys. Res. Lett., 32, L07813, doi:10.1029/2004GL021946, 2005.

Dentener, F., Kinne, S., Bond, T., Boucher, O., Cofala, J., Generoso, S., Ginoux, P., Gong, S., Hoelzemann, J. J., Ito, A., Marelli, L., Penner, J., Putaud, J.-P., Textor, C., Schulz, M., van der Werf, G. R., and Wilson, J.: Emissions of primary aerosol and precursor gases in the years 2000 and 1750 prescribed data-sets for AeroCom, Atmos. Chem. Phys., 6, 4321-4344, doi:10.5194/acp6-4321-2006, 2006.

Desboeufs, K., Losno, R., Vimeux, F., and Cholbi, S.: pH dependent dissolution of wind transported Saharan dust, J. Geophys. Res., 104, 21287-21299, 1999.

Desboeufs, K. V., Sofikitis, A., Losno, R. Colin, J. L., and Ausset, P.: Dissolution and solubility of trace metals from natural and anthropogenic aerosol particulate matter, Chemosphere, 58, 195-203, doi:10.1016/j.chemosphere.2004.02.025, 2005.

Duce, R. A., Liss, P. S., Merrill, J. T., Atlas, E. L., Buat-Menard, P., Hicks, B. B., Miller, J. M., Prospero, J. M., Arimoto, R., Church, T. M., Ellis, W., Galloway, J. N., Hansen, L., Jickells, T. D., Knap, A. H., Reinhardt, K. H., Schneider, B., Soudine, A., Tokos, J. J., Tsunogai, S., Wollast, R., and Zhou, M.: The atmospheric input of trace species to the world ocean, Global Biogeochem. Cycles, 5(3), 193-259, doi:10.1029/91GB01778, 1991.

Erel, Y., Pehkonen, S. O., and Hoffmann, M. R.: Redox chemistry of iron in fog and stratus Clouds, J. Geophys. Res., 98, 1842318434, 1993.

Falkowski, P. G., Barber, R. T., and Smetacek, V.: Biogeochemical controls and feedbacks on ocean primary production, Science, 181, 200-206, doi:10.1126/science.281.5374.200, 1998.

Fan, S.-M., Moxim, W. J., and Levy II, H.: Aeolian input of bioavailable iron to the ocean, Geophys. Res. Lett., 33, L07602, doi:10.1029/2005GL024852, 2006.

Formenti, P., Rajot, J. L., Desboeufs, K., Caquineau, S., Chevaillier, S., Nava, S., Gaudichet, A., Journet, E., Triquet, S., Alfaro, S., Chiari, M., Haywood, J., Coe, H., and Highwood, E.: Regional variability of the composition of mineral dust from western Africa: Results from the AMMA SOP0/DABEX and DODO field campaigns, J. Geophys. Res., 113, D00C13, doi:10.1029/2008JD009903, 2008.

Formenti, P., Schuetz, L., Balkanski, Y., Desboeufs, K., Ebert, M., Kandler, K., Petzold, A., Scheuvens, D., Weinbruch, S., and Zhang, D.: Recent progress in understanding physical and chemical properties of mineral dust, Atmos. Chem. Phys. Discuss., 0, 31187-31251, doi:10.5194/acpd-10-31187-2010, 2010.

Guieu, C., Loye-Pilot, M. D., Ridame, C., and Thomas, C.: Chemical characterization of the Saharan dus end-member: Some biogeochemical implications for the western Mediterranenan Sea, J. Geophys. Res., 107(D15), 4258, doi:10.1029/2001JD000582, 2002.

Guieu, C., Loye-Pilot, M. D., Benyahya, L., and Dufou, A.: Spatial variability of atmospheric fluxes of metals ( $\mathrm{Al}, \mathrm{Fe}, \mathrm{Cd}, \mathrm{Zn}$ and $\mathrm{Pb}$ ) and phosphorus over the whole Mediterranean from a oneyear monitoring experiment: Biogeochemical implications, Mar. Chem., 120, 164-178, doi:10.1016/j.marchem.2009.02.004, 2010.

Hand, J. L., Mahowald, N. M., Chen, Y., Siefert, R. L., Luo, C., Subramaniam, A., and Fung, I.: Estimates of atmosphericprocessed soluble iron from observations and a global mineral aerosol model: Biogeochemical implications, J. Geophys. Res., 109, D17205, doi:10.1029/2004JD004574, 2004.

Hsu, S. C., Wong, G. T. F., Gong, G. C., Shiah, F. K., Huang, Y. T., Kao, S. J., Tsai, F., Lung, S. C. C., Lin, F. J., and Lin, I. I.: Sources, solubility, and dry deposition of aerosol trace elements over the East China Sea, Mar. Chem., 120, 116-127, 2010.

Ito, A. and Feng, Y.: Role of dust alkalinity in acid mobilization of iron, Atmos. Chem. Phys., 10, 9237-9250, doi:10.5194/acp-109237-2010, 2010.

Jickells, T. D. and Spokes, L. J.: Atmospheric Iron Inputs to the Oceans. in The Biogeochemistry of Iron in Seawater, edited by: Turner, D. R. and Hunter, K., SCOR/IUPAC Series, J. Wiley, 85121, 2001.

Jickells, T. D., An, Z. S., Andersen, K. K., Baker, A. R., Bergametti, G., Brooks, N., Cao, J. J., Boyd, P. W., Duce, R. A., Hunter, K. A., Kawahata, H., Kubilay, N., LaRoche, J., Liss, P. S., Mahowald, N., Prospero, J. M., Ridgwell, A. J., Tegen, I., and Torres, R.: Global iron connections between desert dust, ocean biogeochemistry, and climate, Science, 308, 67-71, doi:10.1126/science.1105959, 2005.

Kumar, A. and Sarin, M. M.: Aerosol iron solubility in a semiarid region: temporal trend and impact of anthropogenic sources, Tellus, 62B, 125-132, doi:10.1111/j.1600-0889.2009.00448.x, 2010.

Lafon, S., Rajot, J. L., Alfaro, S. C., and Gaudichet, A.: Quantification of iron oxides in desert aerosols, Atmos. Environ., 38, 1211-1218, doi:10.1016/j.atmosenv.2003.11.006, 2004.

Lazaro, F. J., Gutierrez, L., Barron, V., and Gelado, M. D.: The speciation of iron in desert dust collected in Gran Canaria (Canary Islands): Combined chemical, magnetic and optical analysis, Atmos. Environ., 42, 8887-8896, doi:10.1016/j.atmosenv.2008.09.035, 2008.

Luo, C., Mahowald, N., Bond, T., Chuang, P. Y., Artaxo, P., Siefert, R., Chen, Y., and Schauer, J:, Combustion iron distribution and deposition, Global Biogeochem. Cy., 22, GB1012, doi:10.1029/2007GB002964, 2008.

Mackie, D. S., Peat, J. M., McTainsh, G. H., Boyd, P. W., and Hunter, K. A.: Soil abrasion and eolian dust production: Impli- 
cations for iron partitioning and solubility, Geochem. Geophys. Geosyst., 7, Q12Q03, doi:10.1029/2006GC001404, 2006.

Mahowald, N. M., Baker, A. R., Bergametti. G., Brooks, N., Duce, R. A., Jickells, T. D., Kubilay, N., Prospero. J. M., and Tegen, I.: Atmospheric global dust cycle and iron inputs to the ocean, Global Biogeochem. Cy., 19, GB4025, doi:10.1029/2004GB002402, 2005.

Manktelow, P. T., Mann, G. W., Carslaw, K. S., Spracklen, D. V., and Chipperfield, M. P.: Regional and global trends in sulfate since the 1980s, Geophys. Res. Lett., 34, L14803, doi:10.1029/2006GL028668, 2007.

Manktelow, P. T., Carslaw, K. S., Mann, G. W., and Spracklen, D. V.: The impact of dust on sulfate aerosol, $\mathrm{CN}$ and $\mathrm{CCN}$ during an East Asian dust storm, Atmos. Chem. Phys., 10, 365-382, doi:10.5194/acp-10-365-2010, 2010.

Martin, J. H.: Glacial-interglacial $\mathrm{CO}_{2}$ change: The Iron Hypothesis, Paleoceanography, 5(1), 1-13, doi:10.1029/PA005i001p00001, 1990.

Measures, C. I., Sato, T., Vink, S., Howell, S., and Li, Y. H.: The fractional solubility of aluminium from mineral aerosols collected in Hawaii and implications for atmospheric deposition of biogeochemically important trace elements, Mar. Chem., 120, 146-155, doi:10.1016/j.marchem.2009.01.014, 2010.

Merikanto, J., Spracklen, D. V., Pringle, K. J., and Carslaw, K. S.: Effects of boundary layer particle formation on cloud droplet number and changes in cloud albedo from 1850 to 2000, Atmos. Chem. Phys., 10, 695-705, doi:10.5194/acp-10-695-2010, 2010.

Meskhidze, N., Chameides, W. L., Nenes, A., and Chen, G.: Iron mobilization in mineral dust: Can anthropogenic SO2 emissions affect ocean productivity?, Geophys. Res. Lett., 30, 2085, doi:10.1029/2003GL018035, 2003.

Meskhidze, N., Chameides, W. L., and Nenes, A.: Dust and pollution: A recipe for enhanced ocean fertilization?, J. Geophys. Res., 110, D03301, doi:10.1029/2004JD005082, 2005.

Moore, C. M., Mills M. M., Achterberg, E. P., Geider, R. J., LaRoche, J., Lucas, M. I., McDonagh, E. L., Pan, X., Poulton, A. J., Rijkenberg, M. J. A., Suggett, D. J., Ussher, S. J., and Woodward, E. M. S.: Large-scale distribution of Atlantic nitrogen fixation controlled by iron availability, Nature Geosci., 2, 867-871, doi:10.1038/ngeo667, 2009.

Ooki, A., Nishioka, J., Ono, T., and Noriki, S.: Size dependence of iron solubility of Asian mineral dust particles, J. Geophys. Res., 114, D03202, doi:10.1029/2008JD010804, 2009.

Paris, R., Desboeufs, K. V., Formenti, P., Nava, S., and Chou, C.: Chemical characterisation of iron in dust and biomass burning aerosols during AMMA-SOP1/DABEX: implication for iron solubility, Atmos. Chem. Phys., 10, 4273-4282, doi:10.5194/acp10-4273-2010, 2010.

Planquette, H., Fones, G. R., Statham, P. J., and Morris, P. J.: Origin of iron and aluminum in large particles (>53 micron) in the Crozet region, Southern Ocean, Mar. Chem., 115, 31-42, 2009.

Prospero, J. M., Ginoux, P., Torres, O., Nicholson, S. E., and Gill, T. E.: Environmental characterization of global sources of atmospheric soil dust dandified identified with the NIMBUS 7 Total Ozone Mapping Spectrometer (TOMS) absorbing aerosol product, Reviews Geophys., 40(1), 1002, doi:10.1029/2000RG000095, 2002.

Ridgwell, A.: Global dust cycle, in: Surface Ocean-Lower Atmosphere Processes, edited by: Le Quere, C. L., Saltzman, E. S.,
American Geophysical Union, Washington, DC., 37-56, 2009.

Rijkenberg, M. J. A., Powell, C. F., Dall'Osto, M., Nielsdottir, M. C., Patey, M. D., Hill, P. G., Baker, A. R., Jickells, T. D., Harrison, R. M., Achterberg, E. P.: Changes in iron speciation following a Saharan dust event in the tropical North Atlantic Ocean, Mar. Chem., 110(1-2), 56-67, 2008.

Röthlisberger, R., Bigler, M., Wolff, E. W., Joos, F., Monnin, E., and Hutterli, M. A.: Ice core evidence for the extent of past atmospheric $\mathrm{CO}_{2}$ change due to iron fertilisation, Geophys. Res. Lett., 31, L16207, doi:10.1029/2004GL020338, 2004.

Schepanski, K., Tegen, I., Laurent, B., Heinold, B., and Macke, A. L.: A new Saharan dust source activation frequency map derived from MSG-SEVIRI IR channels, Geophys. Res. Lett., 34, L18803, doi:10.1186/1467-4866-9-7, 2007.

Schroth, A. W., Crusius, J., Sholkovitz, E. R., and Bostick, B. C.: Iron solubility driven by speciation in dust sources to the ocean, Nature Geosci., 2, 337-340, doi:10.1038/NGEO501, 2009.

Sedwick, P. N., Sholkovitz, E. R., and Church, T. M.: Impact of anthropogenic combustion emissions on the fractional solubility of aerosol iron: Evidence from the Sargasso Sea, Geochem. Geophys. Geosyst., 8, Q10Q06, doi:10.1029/2007GC001586, 2007.

Sedlak, D. L., Hoigné, J., David, M. M., Colvile, R. N., Seyffer, E., Acker, K., Wiepercht, W., Lind, J. A., and Fuzzi, S.: The cloudwater chemistry of iron and copper at Great Dun Fell, UK, Atmos. Environ., 31, 2515-2526, 1997.

Shi, Z., Krom, M. D., Bonneville, S., Baker, A. R., Bristow, C., Drake, N., Mann, G., Carslaw, K., McQuaid, J. B., Jickells, T., and Benning, L. G.: Influence of chemical weathering and aging of iron oxides on the potential iron solubility of Saharan dust during simulated atmospheric processing, Global Biogeochem. Cy., 25, GB2010, doi:10.1029/2010GB003837, 2011a.

Shi, Z., Bonneville, S., Krom, M., Carslaw K., Jickells, T., Baker, A., and Benning, L.: Dissolution kinetics of iron in the mineral dust at low $\mathrm{pH}$ during simulated atmospheric processing, Atmos. Chem. Phys., 11, 995-1007, doi:10.5194/acp-11-995-2011, 2011 b.

Shi, Z., Shao, L., Jones, T. P., Whittaker, A. G., Lu, S., Berube, K. A., He, T., and Richards, R. J.:, Characterization of airborne individual particles collected in an urban area, a satellite city and a clean air site in Beijing, 2001, Atmos. Environ., 37, 4097-4108, doi:10.1016/S1352-2310(03)00531-4, 2003.

Shi, Z., Shao, L., Jones, T. P., and Lu, S.: Microscopy and mineralogy of airborne particles collected during severe dust storm episodes in Beijing, China, J. Geophys. Res., 110, D01303, doi:10.1029/2004JD005073, 2005.

Shi, Z., Zhang, D., Hayashi, M., Ogata, H., Ji, H., and Fujiie, W.: Influences of sulfate and nitrate on the hygroscopic behaviour of coarse dust particles, Atmos. Environ., 42, 822-827, doi:10.1016/j.atmosenv.2007.10.037, 2008.

Sholkovitz, E. R., Sedwick, P. N., and Church, T. M.: Influence of anthropogenic combustion emissions on the deposition of soluble aerosol iron to the ocean: Empirical estimates for island sites in the North Atlantic, Geochim. Cosmochim. Acta, 73, 3981-4003, 2009.

Sigman, D. M. and Boyle, E. A.: Glacial/interglacial variations in atmospheric carbon dioxide, Nature, 407, 859-869, 2000.

Solmon, F., Chuang, P. Y. Meskhidze, N., and Chen, Y.: Acidic processing of mineral dust iron by anthropogenic compounds over the north Pacific Ocean, J. Geophys. Res., 114, D02305, 
doi:10.1029/2008JD010417, 2005.

Spokes, L. J. and Jickells, T. D.: Factors controlling the solubility of aerosol trace metals in the atmosphere and on mixing into seawater, Aqua. Geochem., 1, 355-374, 1996.

Spracklen, D. V., Pringle, K. J., Carslaw, K. S., Chipperfield, M. P., and Mann, G. W.: A global off-line model of sizeresolved aerosol microphysics: I. Model development and prediction of aerosol properties, Atmos. Chem. Phys., 5, 22272252, doi:10.5194/acp-5-2227-2005, 2005,

Theodosi, C., Markaki, Z., and Mihalopoulos, N.: Iron speciation, solubility and temporal variability in wet and dry deposition in the Eastern Mediterranean, Mar. Chem., 120, 100-107, doi:10.1016/j.marchem.2008.05.004, 2010.

Turner, S. M., Nightingale, P. D., Spokes, L. J., Liddicoat, M. I., and Liss, P. S.: Increased dimethyl sulphide concentrations in sea water from in situ iron enrichment, Nature, 383, 513-517, doi:10.1038/383513a0, 1996.

Uppala, S. M., Kallberg, P. W., Simmons, A. J., Andrae, U., Bechtold, V. D., Fiorino, M., Gibson, J. K., Haseler, J., Hernandez, A., Kelly, G. A., Li, X., Onogi, K., Saarinen, S., Sokka, N., Allan, R. P., Andersson, E., Arpe, K., Balmaseda, M. A., Beljaars, A. C. M., Van De Berg, L., Bidlot, J., Bormann, N., Caires, S., Chevallier, F., Dethof, A., Dragosavac, M., Fisher, M., Fuentes, M., Hagemann, S., Holm, E., Hoskins, B. J., Isaksen, L., Janssen, P. A. E. M., Jenne, R., McNally, A. P., Mahfouf, J. F., Morcrette, J. J., Rayner, N. A., Saunders, R. W., Simon, P., Sterl, A., Trenberth, K. E., Untch, A., Vasiljevic, D., Viterbo, P., and Woollen, J.: The ERA-40 re-analysis, Q. J. Roy. Meteor. Soc., 131, 29613012, 2005.
Viollier, E., Inglett, P. W., Hunter, K., Roychoudhury, A. N., and Van Cappellen, P.: The ferrozine method revisited: $\mathrm{Fe}(\mathrm{II}) / \mathrm{Fe}(\mathrm{III})$ determination in natural waters, Appl. Geochem., 15, 785-790, 2000.

Woodward, S.: Modelling the atmospheric life cycle and radiative impact of mineral dust in the Hadley Centre climate model, J. Geophys. Res., 106(D16), 18155-18166, 2001.

Zhang, L., Gong, S., Padro, J., and Barrie, L.: A size-segregated particle dry deposition scheme for an atmospheric aerosol module, Atmos. Environ., 35, 549-560, 2001.

Zhu, X., Prospero, J. M., Millero, F. J. Savoie, D. L., and Brass, G. W.: The solubility of ferric ion in marine mineral aerosol solutions at ambient relative humidities, Mar. Chem., 38, 91-107, 1992.

Zhu, X. R., Prospero, J. M., and Millero, F. J.: Diel variability of soluble Fe(II) and soluble total Fe in North African dust in the trade winds at Barbados, J. Geophys. Res., 102(D17), 2129721305, 1997. 